\title{
Pengaruh Konsentrasi Nikel dalam Klorofil pada Sifat Optik dan Konduktivitas Dye untuk Aplikasi Dye-Sensitized Solar Cell (DSSC)
}

\author{
Dinasti Dwi Pratiwi, ${ }^{1}$ Kusumandari, ${ }^{1,2}$ dan Fahru Nurosyid ${ }^{1,2, *}$ \\ ${ }^{1}$ Program Studi Fisika, Pascasarjana, Universitas Sebelas Maret, \\ Jl. Ir. Sutami No. 36 A Kentingan, Jebres, Surakarta 57126 \\ ${ }^{2}$ Program Studi Fisika, Fakultas Matematika dan Ilmu Pengetahuan Alam, \\ Universitas Sebelas Maret, Jl. Ir. Sutami No. 36 A Kentingan, Jebres, Surakarta 57126
}

\begin{abstract}
Intisari
Penelitian ini bertujuan untuk mengetahui pengaruh doping nikel pada dye klorofil terhadap sifat optik dan konduktivitas dalam aplikasi DSSC. Doping nikel difokuskan pada pengaruh konsentrasi nikel pada dye klorofil sebagai fotosensitizer. Analisis sifat optik (absorbansi) larutan dye dan $\mathrm{TiO}_{2}$ menggunakan spektrofotometer UV-Vis. Analisis sifat optik untuk identifikasi gugus fungsional pada $\mathrm{TiO}_{2}$ setelah direndam dye menggunakan spektrofotometer FTIR. Konduktivitas larutan dye dihitung menggunakan I-V meter. Hasil karakterisasi absorbansi dan konduktivitas larutan dye menunjukkan peningkatan sebanding dengan kenaikan konsentrasi doping Ni. Karakterisasi FTIR menghasilkan absorpsi optimum ikatan Ni-Cl pada doping Ni 0,1 M dengan puncak frekuensi $679 \mathrm{~cm}^{-1}$. Absorbansi $\mathrm{TiO}_{2} /$ dye juga menunjukkan hasil optimum pada doping $\mathrm{Ni} 0,1 \mathrm{M}$.
\end{abstract}

\section{ABSTRACT}

\begin{abstract}
This study aims to investigate the effect of nickel doping into chlorophyll dye on the optical properties and conductivity for DSSC application. The nickel doping is focused the effect of nickel concentration into chlorophyll dye as photosensitizer. Analysis of optical properties (absorbance) of dye solutions and $\mathrm{TiO}_{2}$ used the UV-Visible spectrophotometer. The conductivity of dye solutions were calculated using I-V meter. The characterization results of absorbance and conductivity of dye solutions were direcly proportional to increasing the Ni concentration. The FTIR characterization resulted the optimum absorption at a concentration of $0,1 \mathrm{M}$ with the frequency peak of $(\mathrm{Ni}-\mathrm{Cl})$ at $679 \mathrm{~cm}^{-1}$. The absorbance of $\mathrm{TiO}_{2} /$ dye also showed that the optimum doping concentration of $0,1 \mathrm{M}$
\end{abstract}

KATA KUNCI: chlorophyll, nickel, absorbance, conductivity http://dx.doi.org/10.12962/j24604682.v14i3.3761

\section{PENDAHULUAN}

Dye-sensitized solar cells (DSSC) merupakan piranti sel surya berbasis pewarna yang dapat mengkonversi energi surya menjadi energi listrik [1,2]. DSSC telah banyak dikembangkan karena fabrikasi murah dan tidak memerlukan teknologi yang rumit $[1,3]$. Struktur DSSC meliputi substrat kaca konduktif (FTO/ITO), elektroda lawan, pewarna (dye), elektrolit, dan semikonduktor [4-6]. Salah satu faktor yang memengaruhi performa DSSC adalah dye. Dye berperan dalam menyerap dan mengkonversi energi surya menjadi energi listrik [7-9].

Dye alami saat ini banyak digunakan karena murah dan ramah lingkungan. Pemanfaatan dye alami dapat diperoleh dari bagian tumbuhan [10-12]. Dye alami yang sering digunakan sebagai sensitizer DSSC adalah pigmen klorofil [13]. Klorofil merupakan pigmen utama pada tumbuhan hijau yang

\footnotetext{
*E-MAIL: nurosyideyahoo.com
}

sangat efektif dalam proses fotosintesis. Klorofil menyerap panjang gelombang warna merah dan biru dalam spektrum cahaya tampak [14]. Serapan maksimum klorofil dapat mencapai panjang gelombang $670 \mathrm{~nm}$, sehingga pigmen klorofil sesuai dan menarik sebagai sensitizer DSSC [15].

Penelitian ini menggunakan dye klorofil yang dimodifikasi dengan metode pendopingan logam. Logam nikel dicampurkan pada dye klorofil dengan variasi konsentrasi. Logam Ni dipilih karena memiliki konduktivitas listrik yang baik, sehingga diharapkan mampu meningkatkan konduktivitas dye klorofil. Selain itu pendopingan logam Ni dalam dye klorofil diharapkan dapat memperlebar serapan hingga dekat daerah inframerah. Kajian sifat optik pada performa sensitizer dan lapisan semikonduktor merupakan parameter yang sangat berpengaruh terhadap kinerja DSSC [16]. Oleh karena itu, artikel ini melaporkan pengaruh doping nikel pada dye klorofil terhadap sifat optik dan konduktivitas DSSC. Karakteristik optik dye dan lapisan semikonduktor/dye dianalisis dengan spektroskopi serapan UV-Vis dan FTIR, sedangkan konduktivitas dye dianalisis dengan I-V Meter. 


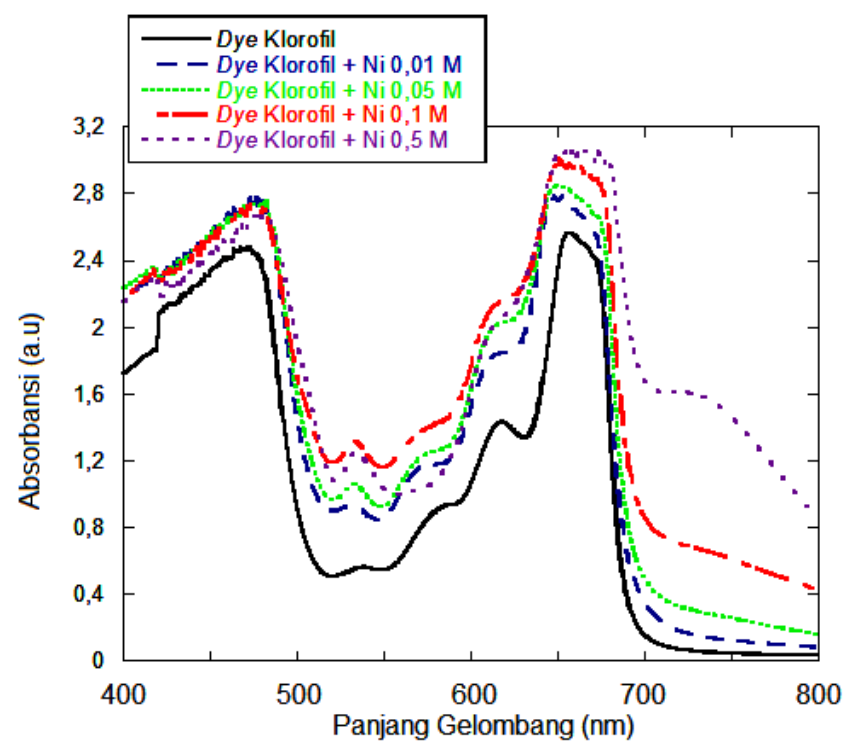

Gambar 1: Spektrum absorpsi UV-Vis larutan dye klorofil dan dye/Ni dengan variasi konsentrasi.

\section{EKSPERIMEN}

Pembuatan pasta $\mathrm{TiO}_{2}$ dengan melarutkan $\mathrm{TiO}_{2}$ transparan 18NR-T (Dyesol) dalam pelarut etanol dengan perbandingan 1:2. Larutan tersebut distirrer selama 1 jam dengan kecepatan putar $300 \mathrm{rpm}$. Pasta $\mathrm{TiO}_{2}$ dideposisikan pada kaca FTO dengan area sel aktif $1,5 \mathrm{~cm} \times 0,5 \mathrm{~cm}$ menggunakan metode spin coating. Lapisan $\mathrm{TiO}_{2}$ diannealing pada suhu $400^{\circ} \mathrm{C}$ selama 10 menit dalam furnace.

Larutan dye diekstrak dari daun bayam organik. Daun bayam dihaluskan pada mortar dan dilarutkan dalam pelarut aseton. Larutan tersebut distirrer agar diperoleh larutan homogen. Larutan dye disaring dengan kertas saring whatman no.42. Garam logam $\mathrm{NiCl}_{2}$ dilarutkan ke dalam dye klorofil dengan variasi konsentrasi $0,01 \mathrm{M} ; 0,05 \mathrm{M} ; 0,1 \mathrm{M}$; dan 0,5 M. Larutan dye dan lapisan $\mathrm{TiO}_{2} /$ dye dianalisis menggunakan spektrofotometer UV-Vis untuk mengetahui absorbansi. Larutan dye juga dianalisis menggunakan Keithley I-V Meter 2602A untuk menghitung nilai konduktivitas. Selanjutnya lapisan $\mathrm{TiO}_{2}$ /dye dianalisis menggunakan spektrofotometer FTIR untuk mengetahui gugus fungsionalnya.

\section{HASIL DAN DISKUSI/PEMBAHASAN}

Larutan dye klorofil diekstrak dari daun bayam organik dengan pelarut aseton. Pengujian absorbansi menggunakan spektrofotometer UV-Vis Lambda 25 yang didapatkan kurva seperti pada Gambar 1. Kurva absorbansi memperlihatkan rentang panjang gelombang 400-800 nm. Daerah sinar tampak (visible) pada rentang 400-700 nm, sedangkan daerah di atas $700 \mathrm{~nm}$ mendekati sinar infra merah merupakan spektrum absorbansi dari nikel klorida.

Gambar 1 tampak bahwa absorbansi dye ekstrak daun

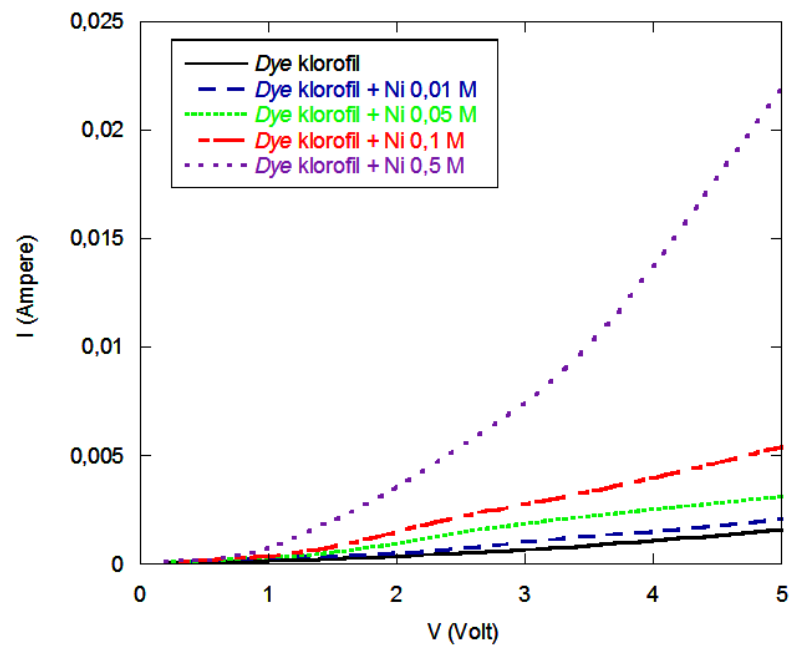

Gambar 2: Kurva konduktivitas larutan dye klorofil dan dye/Ni dengan variasi konsentrasi.

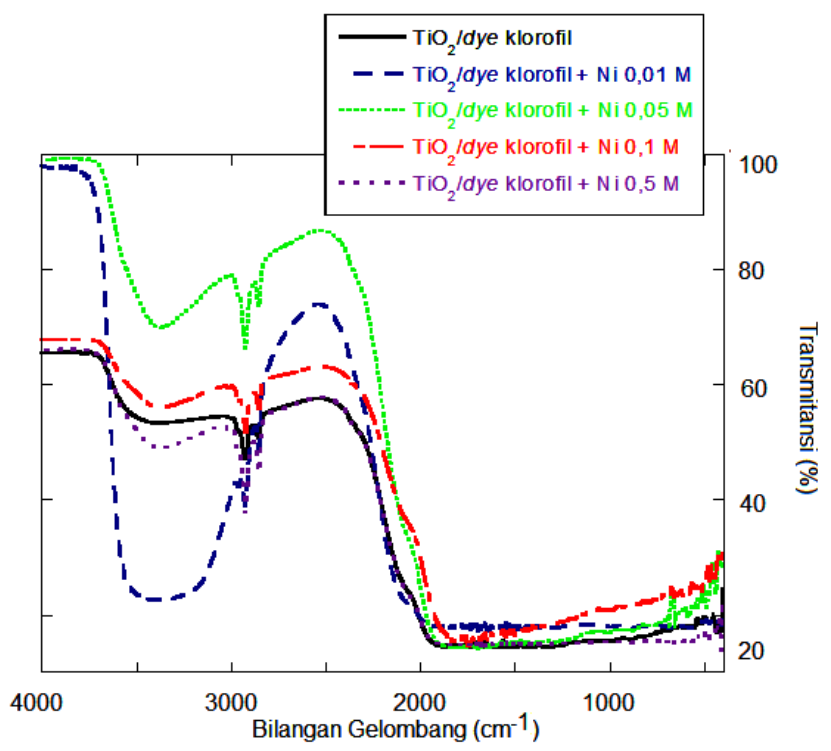

Gambar 3: Spektrum FTIR lapisan $\mathrm{TiO}_{2}$ /dye klorofil dan dye/Ni dengan variasi konsentrasi.

bayam berada pada rentang panjang gelombang 430-490 nm dan 630-700 nm. Daerah tersebut mengindikasikan daerah absorbansi pigmen klorofil. Puncak absorbansi menunjukkan bahwa pada panjang gelombang tersebut serapan foton maksimum maka elektron yang tereksitasi dari HOMO ke LUMO juga banyak. Hal ini menunjukkan bahwa dye ekstrak daun bayam dapat diaplikasikan sebagai fotosensitizer DSSC karena mampu menyerap daerah sinar tampak. Pendopingan Ni pada dye klorofil juga memperluas spektrum absorbansi dari 400-700 nm menjadi lebih lebar ke daerah serapan dekat sinar inframerah hingga $800 \mathrm{~nm}$. Ketika dye dapat mengabsorpsi cahaya pada rentang panjang gelombang yang lebih lebar, maka intensitas penyerapan energi foton semakin efektif sehingga meningkatkan jumlah elektron yang tereksi- 
TABEL I: Data FTIR lapisan $\mathrm{TiO}_{2} /$ dye klorofil dan dye/Ni dengan variasi konsentrasi.

\begin{tabular}{|c|c|c|c|c|c|c|c|c|c|c|}
\hline \multicolumn{2}{|c|}{$\begin{array}{l}\text { D ye Klorofil } \\
\text { Puncak T }(\%)\end{array}$} & \multicolumn{2}{|c|}{$\begin{array}{l}\mathrm{K}+\mathrm{Ni} 0,01 \mathrm{M} \\
\text { Puncak T }(\%)\end{array}$} & \multicolumn{2}{|c|}{$\begin{array}{l}\mathrm{K}+\mathrm{Ni} 0,05 \mathrm{M} \\
\text { Puncak T (\%) }\end{array}$} & \multicolumn{2}{|c|}{$\begin{array}{l}\mathrm{K}+\mathrm{Ni} 0,1 \mathrm{M} \\
\text { Puncak T }(\%)\end{array}$} & \multicolumn{2}{|c|}{$\begin{array}{l}\mathrm{K}+\mathrm{Ni} 0,5 \mathrm{M} \\
\text { Puncak T }(\%)\end{array}$} & Gugus \\
\hline 512 & 18,5 & & & 521 & 21,9 & 514 & 24,1 & 515 & 16 & Ti-O-Ti \\
\hline 547 & 17,7 & & & 555 & 20,9 & 587 & 22,9 & 524 & 15,8 & \\
\hline \multirow[t]{4}{*}{575} & 17,6 & 575 & 17,6 & 583 & 19 & & & 548 & 15,3 & \\
\hline & & & & 651 & 17,8 & 656 & 22,9 & 654 & 14,9 & \\
\hline & & 668 & 17,4 & 683 & 17,6 & 679 & 23,1 & 681 & 14,9 & $\mathrm{Ni}-\mathrm{Cl}$ \\
\hline & & 1553 & 16,9 & & & 1549 & 16,2 & 1578 & 14,9 & $\mathrm{C}=\mathrm{C}-\mathrm{C}$ \\
\hline 1641 & 14 & 1648 & 17 & & & & & & & $\mathrm{C}=\mathrm{C}$ \\
\hline \multirow[t]{3}{*}{1666} & 14 & & & 1670 & 14,1 & & & & & \\
\hline & & & & & & 1713 & 15,4 & & & $\mathrm{C}=\mathrm{O}$ \\
\hline & & & & & & 1745 & 14,6 & & & \\
\hline 2853 & 50,7 & 2851 & 48,7 & 2853 & 73,6 & 2851 & 55,7 & 2852 & 44,7 & $\mathrm{C}-\mathrm{H}$ \\
\hline \multirow[t]{3}{*}{2924} & 47 & 2924 & 38,9 & 2923 & 66 & 2922 & 51,6 & 2922 & 37,8 & \\
\hline & & 2960 & 42,2 & 2955 & 75 & 2957 & 57 & 2957 & 47,3 & \\
\hline & & & & 3013 & 78,5 & 3011 & 59 & 3011 & 51,9 & $\mathrm{O}-\mathrm{H}$ \\
\hline 3393 & 53 & 3399 & 22,5 & 3369 & 69,9 & 3366 & 56 & 3367 & 48,9 & \\
\hline
\end{tabular}

tasi. Variasi konsentrasi nikel klorida pada dye klorofil tidak menggeser posisi puncak absorbansi baik ke arah panjang gelombang lebih pendek atau lebih panjang. Variasi konsentrasi nikel klorida memengaruhi nilai absorbansi pada panjang gelombang $660 \mathrm{~nm}$ dan di atas $700 \mathrm{~nm}$. Penambahan jumlah konsentrasi mengakibatkan peningkatan absorbansi secara linier. Hal ini sesuai dengan hukum Lambert-Beer bahwa absorbansi suatu larutan akan sebanding dengan konsentrasi larutan [17].

Konduktivitas listrik menjadi indikator kemampuan suatu bahan dalam menghantarkan arus listrik. Konduktivitas listrik larutan dye diuji dengan Keithley I-V Meter dengan intensitas penyinaran $1000 \mathrm{~W} / \mathrm{m}^{2}$. Gambar 2 merupakan kurva arustegangan larutan dye klorofil dan klorofil/ $\mathrm{Ni}$ dengan variasi konsentrasi yang diukur dalam kondisi terang. Berdasarkan kurva tersebut tampak bahwa arus listrik meningkat sebanding dengan tegangan.

Nilai konduktivitas listrik larutan dye klorofil sebesar $0,0346 \Omega^{-1} m^{-1}$, sedangkan dye klorofil doping $\mathrm{Ni}$ dengan konsentrasi $0,01 \mathrm{M} ; 0,05 \mathrm{M} ; 0,1 \mathrm{M}$; dan $0,5 \mathrm{M}$ masing-masing menghasilkan nilai konduktivitas listrik sebesar $0,0598 \Omega^{-1} m^{-1} ; 0,0906 \Omega^{-1} m^{-1} ; 0,132 \Omega^{-1} m^{-1}$; dan $0,333 \Omega^{-1} m^{-1}$. Hasil menunjukkan peningkatan nilai konduktivitas yang sebanding dengan peningkatan konsentrasi $\mathrm{Ni}$ yang ditambahkan pada dye klorofil. Pendopingan Ni pada dye klorofil memiliki kemampuan dalam menghasilkan arus listrik yang baik, sehingga diharapkan lebih konduktif ketika menyerap cahaya.

Hasil analisis FTIR lapisan $\mathrm{TiO}_{2} /$ dye dan dye/Ni ditunjukkan pada Gambar 3. Kurva pada Gambar 3 dapat diinterpretasikan dalam Tabel I. Tabel I menyajikan kandungan gugus fungsional dan frekuensi vibrasi dari lapisan $\mathrm{TiO}_{2} /$ dye dan dye/Ni. Hasil FTIR menunjukkan adanya gugus $\mathrm{O}-\mathrm{H}$ strecthing Ti-O-Ti pada lapisan $\mathrm{TiO}_{2}$. Gugus O-H pada dye klorofil/Ni 0,01 M menunjukkan degradasi yang signifikan karena dye dan lapisan $\mathrm{TiO}_{2}$ terjadi kontak yang lemah, sehingga menghambat transfer elektron. Absorpsi optimum terjadi pada dye klorofil/Ni $0,1 \mathrm{M}$ dengan adanya ikatan $\mathrm{Ni}-\mathrm{Cl}$

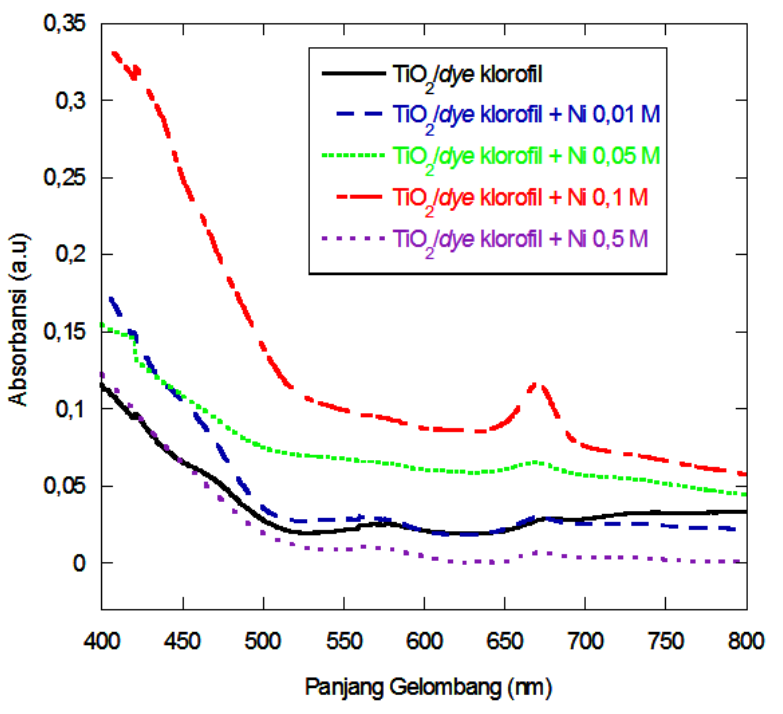

Gambar 4: Spektrum absorpsi UV-Vis lapisan $\mathrm{TiO}_{2} /$ dye klorofil dan dye/Ni dengan variasi konsentrasi.

dan Ti-O-Ti yang memiliki transmitansi $23,1 \%$ dan $24,1 \%$ pada bilangan gelombang $679 \mathrm{~cm}^{-1}$ dan $514 \mathrm{~cm}^{-1}$. Hal ini memengaruhi coupling elektron pada pita konduksi $\mathrm{TiO}_{2}$ yang mempercepat transfer elektron. Hasil analisis FTIR ini juga didukung dengan absorbansi $\mathrm{TiO}_{2}$ /dye pada Gambar 4 . Gambar 4 merupakan serapan cahaya dari lapisan $\mathrm{TiO}_{2}$ setelah direndam dengan dye klorofil dan dye klorofil doping $\mathrm{Ni}$. Kurva memperlihatkan bahwa pada konsentrasi 0,1 M menunjukkan hasil optimum dengan serapan tertinggi dibandingkan dengan konsentrasi lainnya. Hal ini dapat dijelaskan karena dye klorofil + Ni 0,1 M teradsorpsi pada permukaan semikonduktor $\mathrm{TiO}_{2}$ dengan baik, sehingga kontak antara molekul dye aktif dengan lapisan $\mathrm{TiO}_{2}$ terjadi interaksi yang kuat. Selain itu kromofor dye klorofil/Ni 0,1 M lebih banyak berikatan dengan ion $\mathrm{Ti}^{+}$sehingga elektron yang tereksitasi semakin 
banyak ketika terjadi penyerapan foton. Namun pada lapisan $\mathrm{TiO}_{2}$ yang direndam dengan dye klorofil+Ni 0,5 M menunjukkan serapan paling rendah karena adanya precipitation effect pada lapisan $\mathrm{TiO}_{2}$, sehingga laju transfer elektron dari dye ke lapisan $\mathrm{TiO}_{2}$ menjadi terhambat. Kondisi ini berakibat meningkatnya molekul dye yang tidak aktif dan kontak dengan permukaan $\mathrm{TiO}_{2}$ menjadi lemah.

Kajian penelitian yang relevan dengan penelitian ini adalah pendopingan logam $\mathrm{Cu}$ pada dye antosianin Oriza sativa L. indica oleh Fadli et al. (2016). Hasil penelitian tersebut menunjukkan spektrum absorbansi pada rentang panjang gelombang sinar tampak hingga $600 \mathrm{~nm}$. Pendopingan $\mathrm{Cu}$ pada dye antosianin hanya meningkatkan nilai puncak absorbansi, tapi tidak memperlebar daerah absorpsi seperti pada pendopingan $\mathrm{Ni}$ pada dye klorofil. Karakteristik konduktivitas pendopingan logam $\mathrm{Cu}$ pada dye antosianin mengalami fluktuatif saat kenaikan jumlah konsentrasi doping $\mathrm{Cu}$. Hasil optimum diperoleh pada pendopingan $\mathrm{Cu} 4 \operatorname{gram}(0,9 \mathrm{M})$ yang menunjukkan peningkatan konduktivitas hingga 3,5 kali dari dye antosianin murni. Pendopingan Ni pada dye klorofil meningkatkan nilai konduktivitas hampir 10 kali dibandingkan dye klorofil murni pada konsentrasi tertinggi $0,5 \mathrm{M}$.

\section{SIMPULAN}

Pendopingan nikel pada dye klorofil memengaruhi peningkatan nilai absorbansi dan konduktivitas. Namun saat diaplikasikan dalam perendaman semikonduktor $\mathrm{TiO}_{2}$ memiliki hasil optimum pada konsentrasi 0,1 M. Hasil FTIR pada konsentrasi $0,1 \mathrm{M}$ menunjukkan ikatan $\mathrm{Ni}-\mathrm{Cl}$ dan $\mathrm{Ti}$ $\mathrm{O}-\mathrm{Ti}$ yang memengaruhi coupling elektron pada pita konduksi $\mathrm{TiO}_{2}$ yang mempercepat transfer elektron. Analisis ini juga didukung pada absorbansi $\mathrm{TiO}_{2}$ pada konsentrasi $0,1 \mathrm{M}$ bahwa terjadi interaksi yang baik antara molekul dye aktif dengan permukaan $\mathrm{TiO}_{2}$.

\section{Ucapan Terima Kasih}

Penelitian ini didukung oleh hibah Penelitian Unggulan Lembaga Penelitian dan Pengabdian Masyarakat (LPPM), Universitas Sebelas Maret (Nomor kontrak: 543/UN27.21/PP/2018).
[1] B. Oregan dan M. Gratzel, "A low-cost, high-efficiency solar cell based on dye-sensitized colloidal TiO2 films", Nature, vol. 353, pp. 737-740, 1991.

[2] H. Zhang, Y. Han, X. Liu, P. Liu, H. Yu, S. Zhang, dan H. Zhao, "Anatase $\mathrm{TiO}(2)$ microspheres with exposed mirror-like plane 001 facets for high performance dye-sensitized solar cells (DSSCs)", Chem. Commun., vol. 46, pp. 8395-8397, 2010.

[3] J. Gong, J. Liang, dan K. Sumathy, "Review on dye-sensitized solar cells (DSSCs): Fundamental concepts and novel materials", Renew. Sustain. Energy. Rev., vol. 16, pp. 5848-5860, 2012.

[4] M.A.M. Al-Alwani AB Mohamad, NA Ludin, AAH Kadhum, K Sopian, "Dye-sensitised solar cells: Development, structure, operation principles, electron kinetics, characterisation, synthesis materials and natural photosensitisers", Sustain. Energy. Rev., 65, 183-213 (2016).

[5] S. Sharma, B. Siwach, S.K. Ghoshal, dan D. Mohan, "Dye sensitized solar cells: From genesis to recent drifts", Renew. Sustain. Energy. Rev., vol. 70, pp. 529-537, 2017.

[6] Y. Ooyama dan Y. Harima, "Photophysical and electrochemical properties, and molecular structures of organic dyes for dyesensitized solar cells.", Chem. Phys. Chem., vol. 13, no. 18, pp. 4032-4080, 2012.

[7] A. Blaszczyk, "Strategies to improve the performance of metalfree dye-sensitized solar cells", Dyes and Pigments, vol. 149, pp. 707-718, 2018.

[8] X.F. Wang dan H. Tamiaki, "Cyclic tetrapyrrole based molecules for dye-sensitized solar cells", Energy. Environ. Sci., vol. 3, pp. 94-106, 2010.

[9] N. Yazie, D. Worku, dan A. Reda, "Natural dye as light- harvesting pigments for quasi-solid-state dye-sensitized solar cells", Mater. Renew. Sustain. Energy, 5:13, 2016.

[10] H. Hug, M. Bader, P. Mair, dan T. Glatzel, "Biophotovoltaics: natural pigments in dye-sensitized solar cells", Appl. Energy, vol. 115, pp. 216-225, 2015.

[11] N.A. Ludin, A.M.A. Mahmoud, A.B. Mohamad, A.A.H. Kadhum, K. Sopian, dan N.S.A. Karim, Renew. Sustain. Energy, 31, 386-396 (2014).

[12] G. Richhariya, A. Kumar, P. Tekasakul, dan B. Gupta, ”Review on the development of natural dye photosensitizer for dyesensitized solar cells", Renew. Sustain. Energy, vol. 69, pp. 705$718,2017$.

[13] Z. Arifin, S. Soeparman, D. Widhiyanuriyawan, dan Suyitno, "Improving Stability of Chlorophyll as Natural Dye for DyeSensitized Solar Cells", Jurnal Teknologi, vol. 80, no. 1, pp. 2733, 2018.

[14] J. Gross, "Pigments in Vegetables Chlorophylls and Carotenoids", Boston: Springer-US, 1995.

[15] Y. Amao, Y. Yamada, dan K. Aoki, "Preparation and properties of dye-sensitized solar cell using chlorophyll derivative immobilized $\mathrm{TiO}_{2}$ film electrode", Photochems. Photobiol A: Chems., vol. 164, pp. 47-51, 2004.

[16] D.D. Pratiwi, F. Nurosyid, A. Supriyanto, dan R. Suryana, ”Optical properties of natural dyes on the dye-sensitized solar cells (DSSC) performance", J. Phys.: Conf. Ser., vol. 776, no. 1, 012007 (2016).

[17] Dachriyanus, "Analisis Struktur Senyawa Organik Secara Spektroskopi”, Andalas University Press, 2004. 